Pakistan Journal of Education

Vol.36, No.2, 2019, 77-89

\title{
Global Citizenship Skills among University Students and its Relationship with their Identity Orientation
}

\author{
Muhammad Ayub Buzdar* \\ Bushra Noreen $^{* *}$ \\ Azhar Mumtaz Saadi ${ }^{* *}$
}

\begin{abstract}
Development of citizenship skills is a core purpose of schooling. It helps the students to compete social and professional challenges in their practical lives. Major purpose of the current study was to examine the prevalence of global citizenship skills among university students in Pakistan and its relationship with their identity orientations. Three indicators of global citizenship including social responsibility, global competence and global civic engagement were accepted to execute the research objective. The study followed four aspects of identity orientations including personal, social, collective and relational orientations. 324 students enrolled in selected Pakistani public sector universities participated in the study. Aspects of Identity Questionnaire (AIQ-IV) developed by Cheek and Briggs (2013) and global citizenship scale developed by Morais and Ogden (2011) were adapted as research instruments to collect the required data. Results show that the prevalence of global civic engagement and social responsibility is comparatively lesser among the participants than other global citizenship skills. The students supported all four types of identity orientations. The study concludes that the four identity orientations have significant and direct associations with the major global citizenship skills.
\end{abstract}

Keywords: engagement; intercultural communication; global competence; social identity.

\footnotetext{
* Assistant Professor, Department of Education, Government College University Faisalabad (Corresponding Author) Email: ayubbuzdar@gmail.com

** Assistant Professor, Department of Education, Government College University Faisalabad

*** Assistant Professor, Department of Educational Planning, Policy Studies and Leadership (EPPSL), Allama Iqbal Open University Islamabad
} 


\section{Introduction}

The concept of global citizenship demands that the citizens of any country should be aware of their relationships with the world. Theorists of citizenship offer detail code and direction of living and responding in a politically global community. These guidelines include standards of living with human dignity and ethics in a global sphere (Cabrera, 2010). The results of this exercise are emerged as a set of global duties for individuals. These duties range from humanitarian contributory activities to global governance, security and justice. Observance of these activities makes any individual responsible and effective member of the global society. Schattle (2010) claims that the global citizenship has three major dimensions: social responsibility, global competence and global civic engagement. The three dimensions are interrelated and show how state and non-state elements shape peoples' mind towards a diversified but global community. Education as a social activity provides theoretical and philosophical foundations to the state and non-state organizations that are responsible of the global upbringing of the children.

Social responsibility is believed to having social concerns of others in the world and environment (Braskamp, 2008). Social responsibility is to acknowledge the needs of social surroundings including environment and human and non-human elements as well as making efforts to make the society compatible and friendly for all. The students who are socially responsible are more critical to many problems of their society and globe especially in terms of social injustice and disparities against marginalized groups of the society (Westheimer \& Kahne, 2004). They are also aware of the requirements of their environment. They have concerns of global warming, different types of pollution and deteriorating climate of the globe. As a responsible global citizen their efforts are to reduce these challenges and contribute effectively with their fellows in this endeavor.

Another indicator of social responsibility is tolerance and respect for opponent views in local as well as global context. The world is full of diversities. Major prevailing diversities include ideological, religious, political, ethnical, lingual, financial and racial. A globally responsible citizen is aware of the fundaments of these diversities and has respect and acceptability for the people of opponent ideas. A responsible citizen accepts the rights of her opponents and attempts to not violate these rights in case of any conflicts and even in war. Education as an instrument is to inculcate the sense of these responsibilities in the 
individuals. It prepares the students to act individually and collectively in favor of all citizens and environment.

The concept of global competence also rests on the assumption of understanding other viewpoints. The global competence, in real sense, is the competency and skill of effectively communicating people of diversified backgrounds and cultures weighing their social, cultural and environmental differences (Deardorff, 2006). The global competence requires acquiring sufficient knowledge of self, others and global values for inter cultural communications. It is also necessary, as part of global competence, that students should have skills to approach, explore and understand self, others and globe. Global values are universal but many times locally driven. Global competence enables the individual to understand global principles and rules in local context so that a harmony can be developed in different perspectives that are pre-dominantly local and indigenous. Inhabitants of different communities interact with each other and develop a community of harmonious and peaceful people. Individuals' skills that enable them to understand each other and accommodate each other's life styles and beliefs are symbols of their global competence.

The third dimension of global citizenship i.e. global civic engagement is meant to active participation of individuals in the efforts of resolving global issues. It is the behavior of individuals through community participation and active volunteerism (Parekh, 2003). A global citizen should have awareness of the local and global issues and emerging challenges. It helps her to participate actively in activities that are initiated to overcome these issues. An individual participation and contribution in such activities is the essence of global engagement. Global civic engagement provides individual opportunities to think locally and act globally. Individuals through this engagement accept their global roles and act as responsible international citizen. It also helps in broadening their vision of life and universe. Various international forums provide opportunities of participation and contribution collectively to volunteers residing in various parts of the globe.

Literature supports the idea that the presence of social responsibility, global competence and civic engagement collectively shapes an effective global citizen. The three dimensions of global citizenships also cover fundamental requirements for living in a peaceful and live-able society and world. One major objective of education in this context is to prepare effective global citizens in educational institutions. Literature also reveals that many students however in this process face confusion and rift in their roles as global citizens and indigenous 
inhabitants (Parmenter, 2011; and Yemini, 2018). It is observed that in many cases people find it difficult to accommodate their local and international responsibilities simultaneously. This study was designed to examine the scenario of Pakistani education and students in this regard. Focus, in the study, remains on finding relationships between the prevalence ofthree dimensions of global citizenships among the university students and its relationship with their identity orientations.

The second variable accepted in this study id students' identity orientation. Identity, in general concept, is the self-conceptualization of any individual. People accept various social and psychological attributes in the process of self-conceptualization and identity formation. They construct self-images which help them in placing themselves in different social groups and sometimes in socio-economic categories (Hagger, Anderson, Kyriakaki, \& Darkings, 2007). Basis of constructing selfimages are diversified and vary individual to individual and group to group. Religion, ethnicity, race, nationality and gender are major determinants of identity. Cheek (1989) has theorized that individuals generally prefer to follow between personal, social, and collective identity orientations. The personal identity orientation (PI) is persons' private perception and subjective feelings about self. These personal views about the self fundamentally give justification to individuals' personal beliefs and thoughts - the thoughts that are accepted by individual for internal actualization. The social identity orientation (SI), on the other hand, concentrates on social images of individuals in society and wider public. Individuals, in social identity orientation, are concerned with their social image and acceptability in the society. People under this orientation shape themselves to develop an identity within social context rather than focusing on internal and personal wellbeing. The collective identity orientation (CI) is association with particular social, religious, national or ethnic group. This is basically group identity. People in collective identity orientation develop a bondage and connection forming a group and use that group as major source of their identity. The basis of developing these groups may be religious, lingual, ethnic, racial, national, economic etc. The vested interests of within group people function as binding force for these groups. Another category "relational identity orientation" (RI) focuses on framing associations in response to others' welcoming and caring behaviors(Cheek, Smith, \& Tropp, 2002). The relational identity orientation is developed in response and relies on external sources. People in this category may shape their identity to welcome or avoid any external factor. The viability of these types of identity are majorly 
depends on that external factors. The nature of relational identity orientation is inconsistent and changeable. Research demonstrates that the presence of different identity orientations may vary in individuals depending on different social and societal factors (Carpenter \& Karakitapoglu-Aygün, 2005).

\section{The Current Study}

The current study aims to examine the relationships between the identity orientations of university students and their acceptance for the major dimensions of global citizenship. Four dimensions of identity orientations presented by Cheek, Smith, and Tropp (2002) including personal identity, social identity, collective identity and relational identity were accepted to achieve the part of research objectives. Three aspects of global citizenship including social responsibility, global competence and global civic engagement adapted from Morais and Ogden (2011) to conceptualize the concept of global citizenship for the inquiry. Quantitative research approach is followed to find out the relationships among the different dimensions of two variables.

\section{Research Method}

The inquiry followed descriptive approach of scientific investigation. Basic purpose of the inquiry was to examine relationship between the prevalence of global citizenship skills among the university students and its association with their identity orientations. 360 students enrolled in six academic departments of two universities were invited to participate in the study. Aspects of Identity Questionnaire (AIQ-IV) developed by Cheek and Briggs (2013) and global citizenship scale developed by Morais and Ogden (2011) were adapted as research instruments to collect the required data. The AIQ-IV comprises 45 items and 4 sub-factors including Personal Identity Orientation, Relational Identity Orientation, Social Identity Orientation, and Collective Identity Orientation. The global citizenship scale has 30 items and 3 subscales including social responsibility, global competence and global civic engagement. The subscale 'global competence' further consisted of 3 factors including self-awareness, intercultural communication, and global knowledge. Minor changes were made in the statements/questions of the aforementioned tools to make them compatible with the Pakistani sample. The validity of the instrument was also ensured through expert opinions and pilot study. Research topic, research objectives, sample information and the selected research instruments were provided to 5 
senior faculty members working in the field of sociology of education. Suggestions provided by the experts were incorporated in the instruments. 200 university students participated in the pilot study. The participants were asked to identify any ambiguity and difficulty in understanding statements of the instruments. It was encouraging that all participants of pilot study demonstrated satisfaction with the face and contents of the instruments. The scales and subscales demonstrated the values of Chronbach Alpha coefficients ranging from .70 to .80 . Finalized questionnaire was administered to 360 selected university students. 324 university students returned the duly filled questionnaires.

\section{Research Findings}

The university students in the sample report that the prevalence of different global citizenship skills is at comparatively moderate level in major except the global civic engagement in which the students' involvement remain comparatively weak $(\mathrm{M}=2.85)$. The prevalence of self-awareness and global knowledge is comparatively higher among the students in the sample (Table 1). For the students' responses on the aspects of identity questionnaire (AIQ-IV), the presences of relational identity orientation $(\mathrm{M}=3.95)$ and collective identity orientation (3.93) remained comparatively higher. The mean scores to represent the prevalence of personal and social identity orientations are 3.83 and 3.65 respectively.

Table 1

Mean scores presenting the university students' global citizenship skills and their preferred identity orientations

\begin{tabular}{lll}
\hline Statement & Mean & SD \\
\hline Global Citizenship Scale & & \\
Social Responsibility & 3.09 & .727 \\
Global Competence & 3.41 & .575 \\
Self-Awareness & 3.47 & .702 \\
Intercultural Communication & 3.29 & .977 \\
Global Knowledge & 3.45 & .780 \\
Global Civic Engagement & 2.85 & .881 \\
\hline Aspects ofIdentity Questionnaire & & \\
Personal Identity Orientation & 3.83 & .662 \\
Relational Identity Orientation & 3.95 & .630 \\
Social Identity Orientation & 3.65 & .695 \\
Collective Identity Orientation & 3.93 & .586 \\
\hline
\end{tabular}


Social responsibility, an indicator of global citizenship skills, has no significant correlation with the any of four aspects of identity orientations (Table 2). The global competence that is another aspect of global citizenship skills has direct significant correlations with the four aspects of identity orientations. The sub-factors of global competence including self-awareness, intercultural communication and global knowledge also demonstrate similar trends. The prevalence of global civic engagement is emerged directly associated with the personal, relational and social identity orientations.

Table 2

Values of Pearson correlation coefficient to show the relationships between the global citizenship skills of the university students and their identity orientations

\begin{tabular}{lllll}
\hline Global Citizenship Scale & $\begin{array}{l}\text { Personal } \\
\text { Identity }\end{array}$ & $\begin{array}{l}\text { Relation } \\
\text { al } \\
\text { Identity }\end{array}$ & $\begin{array}{l}\text { Social } \\
\text { Identity }\end{array}$ & $\begin{array}{l}\text { Collective } \\
\text { Identity }\end{array}$ \\
\hline Social Responsibility & -.086 & -.102 & -.064 & -.108 \\
Global Competence & $.326^{* *}$ & $.355^{* *}$ & $.363^{* *}$ & $.335^{* *}$ \\
Self-Awareness & $.321^{* *}$ & $.249^{* *}$ & $.242^{* *}$ & $.249^{* *}$ \\
Intercultural Communication & .129 & $.168^{* *}$ & $.217^{* *}$ & .140 \\
Global Knowledge & $.269^{* *}$ & $.350^{* *}$ & $.313^{* *}$ & $.339^{* *}$ \\
Global Civic Engagement & $.270^{* *}$ & $.165^{*}$ & $.212^{* *}$ & .151 \\
\hline
\end{tabular}

Note:

* The value of Pearson correlation coefficient is significant at the level of .01 .

** The value of Pearson correlation coefficient is significant at the level of .05 .

\section{Discussion}

Global citizenship is a modern concept which encourages positive and productive relationships among the people of different countries and cultures. This study reveals the self-reported status of young Pakistani students on a global citizenship scales. The three indicators of the global citizenship as postulated by Morais and Ogden (2011) were accepted in the study. These indicators include social responsibility, global competence and global civic engagement. The global competence was further divided in three sub-factors including self-awareness, intercultural communication, and global knowledge. Results reveal that the students rate their global civic engagement lesser than the other indicators. Similarly their self-assessment about performing social responsibilities places them on average. The 
prevalence of global competence and its sub factors is reported comparatively higher. It is important that the students self-reported intercultural communication skills are comparatively lesser than their self-awareness and global knowledge. This part of research findings is understandable in the context of Pakistani society and contemporary education system. Students in Pakistani education system in Pakistan are given limited opportunities of interacting and collaborating on international forums especially for any global cause (Pasha, 2015), which generally emerge as globally less aware and to some extent less engaged citizens. The students' self-assessment of their global competence especially their skills of inert-cultural communication is also supported by previous studies conducted in Pakistani context (Nawaz, Amin, \& Tatlah, 2016).

The students' self-reporting of the aspects of identity questionnaire is used to examine their identity orientations. It is found that the prevalence of all four identity orientations including personal, relational, social and collective identity orientations are significantly higher among the participants. Hussain (2005) has identified that the preference parameters of framing social and personal identities among Pakistani people are different. The people's religious, sectarian, and ethnic differences effect their identity formation. A comparison of the results of current inquiry also reveals such differences highlighting that the presence of relational and collective identities is higher among the university students included in the sample than other identity orientations. The presence of social identity orientation is comparatively lesser among the research participants than the other forms of orientations.

The results of correlation co-efficient establish relationship between different indicators of global citizenship and identity orientations. The prevailing social responsibility among the university students is not associated with any form of identity orientation. The global competence on the other side demonstrates direct, statistically significant and comparatively stronger relationships with all four forms of identity orientation. The indicator of global civic engagement has direct, statistically significant and comparatively weaker association with all four identity orientations. The findings of the inquiry are consistent with global data that explain that the indicators of global identity are negatively correlated with outgroup hostility and hatred (Ariely, 2017). Findings of this study also verify that the indicators of global citizenship including global competence and global civic engagement are directly associated with all form of social identities. 


\section{Conclusions}

The study was conducted to examine the relationship between different indicators of global citizenship and the university students' preferences for different identity orientations. Presence of three categories of global citizenship skills including social responsibility, global competence and global civic engagement were investigated as a part of this inquiry. It is found that the presence of global civic engagement is comparatively lesser in the sample of university students than other indicators of global citizenship i.e. social responsibility and global competence. The prevalence of social responsibility is on average. The students' self-assessment shows that the presence of global competence and its three sub factors is comparatively higher among the sample. In the context of Pakistani education system, where the students have lesser opportunities to engage themselves in global academic and philanthropic activities, the findings of the inquiry are understandable. It is evident that the students in Pakistani universities show the presence of social competence and social responsibility but simultaneously they have lesser opportunities and chances to enhance their engagement in global civic activities.

Prevalence of three identity orientations including personal identity orientation, relational identity orientation, social identity orientation and collective identity orientation were examined as another part of the inquiry. The results of the data analysis show that the university students demonstrate comparatively higher level of preference for the three identity orientations. The prevalence of collective identity orientation and relational identity orientation is comparatively higher in the sample. It reflects the general atmosphere of the Pakistani society and identity preferences of the Pakistani university students. Pearson correlation coefficient test was run to find out the association among the indicators of global citizenship skills and the four identity orientations. Results show that the prevalence of social responsibility cannot demonstrate significant correlation with any of the identity orientations. The relational identity which is based on framing individuality and selfimage on responding others' behaviors has significant and direct associations with the global civic engagement and global competence. The prevalence of personal, social and collective identities has also correlations with the global competence, its sub factors as well as global civic engagements. Results show that, in the Pakistani sample, out of four aspects of identity no one is indirectly associated with any of global citizenship skill. Pakistani university students - who follow personal, 
social, collective or relational aspect of identity-support global citizenship promoting global and social well-being.

\section{Research Applications}

Education in modern concept is considered an activity that facilitates holistic development of the students. The students in contemporary world are required to interact with people around the globe. Findings of this study may help in designing an education program that support global interaction of students respecting indigenous and local values especially in Pakistani context. The study although demonstrates encouraging trends however there is need to further strengthen these behaviors. The data show weaknesses in students' engagement in global civic activities and social responsibility. The study recommends curricular management of providing opportunities to the students which enable them to participate in global level civic and social activities. Further research is recommend in the field to find out the mediating and moderating roles of different factors in explaining the relationships between the variables investigated in this inquiry. 


\section{References}

Ariely, G. (2017). Global identification, xenophobia and globalisation: A cross-national exploration. International Journal of Psychology: Journal International De Psychologie, 52 Suppl 1, 87-96. https:// doi.org/10.1002/ijop.12364

Braskamp, L. A. (2008). Developing Global Citizens. Journal of College and Character, 10(1). https://doi.org/10.2202/1940-1639.1058

Cabrera, L. (2010). The Practice of Global Citizenship. New York: Cambridge University Press.

Carpenter, S., \& Karakitapoglu-Aygün, Z. (2005). Importance and Descriptiveness of Self-Aspects: A Cross-Cultural Comparison, Importance and Descriptiveness of Self-Aspects: A Cross-Cultural Comparison. Cross-Cultural Research, 39(3), 293-321. https://doi.org/ $10.1177 / 1069397104273989$

Cheek, J. M. (1989). Identity Orientations and Self-Interpretation. In D. M. Buss \& N. Cantor (Eds.), Personality Psychology: Recent trends and emerging directions (275-285). New York, NY: Springer. https://doi.org/10.1007/978-1-4684-0634-4 21

Cheek, J. M., \& Briggs, S. R. (2013). Aspects of Identity Questionnaire (AIQ-IV). Measurement Instrument Database for the Social Science. Retrieved July 22, 2018, from http://www.midss.org/content/aspectsidentity-questionnaire-aiq-iv

Cheek, J. M., Smith, S. M., \& Tropp, L. R. (2002, February). Relational identity orientation: A fourth scale for the AIQ. Presented at the Meeting of the Society for Personality and Social Psychology, Savannah, GA.

Deardorff, D. K. (2006). Identification and Assessment of Intercultural competence as a Student Outcome of Internationalization. Journal of Studies in International Education, 10(3), 241-266. https://doi.org/ $10.1177 / 1028315306287002$ 
Hagger, M. S., Anderson, M., Kyriakaki, M., \& Darkings, S. (2007). Aspects of identity and their influence on intentional behavior: Comparing effects for three health behaviors. Personality and Individual Differences, 42(2), 355-367. https://doi.org/10.1016/ j.paid.2006.07.017

Hussain, R. (2005). The effect of religious, cultural and social identity on population genetic structure among Muslims in Pakistan. Annals of Human Biology, 32(2), 145-153. https://doi.org/10.1080/ 03014460500075167

Morais, D. B., \& Ogden, A. C. (2011). Initial Development and Validation of the Global Citizenship Scale, Initial Development and Validation of the Global Citizenship Scale. Journal of Studies in International Education, 15(5), 445-466. https://doi.org/10.1177/ 1028315310375308

Nawaz, H., Amin, D. M., \& Tatlah, D. I. A. (2016). Intercultural Communication and an English Language Classroom: A Study Of Need in a Higher Education Context of Pakistan. The Sindh University Journal of Education - SUJE, 45(1). Retrieved from http://sujo.usindh.edu.pk/index.php/SUJE/article/view/2587

Parekh, B. (2003). Cosmopolitanism and Global Citizenship. Review of International Studies, 29(1), 3-17.

Parmenter, L. (2011). Power and place in the discourse of global citizenship education. Globalisation, Societies and Education, 9(3-4), 367-380. https://doi.org/10.1080/14767724.2011.605322

Pasha, A. (2015). Global citizenship in Pakistan. International Journal of Development Education and Global Learning, 7(1), 33-52. https://doi.org/10.18546/IJDEGL.07.1.03

Schattle, H. (2010). Global Citizenship in Theory and Practice. In R. Lewin (Ed.), The handbook of practice and research in study abroad: Higher education and the quest for global citizenship (3-18). New York: Routledge. https://doi.org/10.4324/9780203876640-8 
Westheimer, J., \& Kahne, J. (2004). What Kind of Citizen? The Politics of Educating for Democracy, What Kind of Citizen? The Politics of Educating for Democracy. American Educational Research Journal, 41(2), 237-269. https://doi.org/10.3102/00028312041002237

Yemini, M. (2018). Global/local nexus: between global citizenship and nationalism in a super-diverse London school. International Studies in Sociology of Education, 27(2-3), 271-287. https://doi.org/10.1080/ 09620214.2018 .1429946

\section{Citation of this Article:}

Buzdar, M. A., Noreen, B., \& Saadi, A. M. (2019). Global citizenship skills among university students and its relationship with their identity orientation. Pakistan Journal of Education, 36(2),77-89 